\title{
The Analysis of Permeability and Mechanical Properties of Sand Moulding Using Mixed Material Clamshell (Placuna placenta) on Sand Casting
}

\author{
Kritchakhris Nawettanaprasert $^{1}$, Zakaria Bagus Aminanta ${ }^{2,3}$, and Putut Murdanto ${ }^{2}$ \\ ${ }^{1}$ Department of Industrial Engineering, Faculty of Industrial Engineering, Phranakhon Rajabhat University, Thailand \\ 2 Department of Mechanical Engineering, Faculty of Engineering, Universitas Negeri Malang \\ 3 Bachelor Program, Mechanical Engineering Department, Universitas Negeri Malang \\ *zakariabagus20@gmail.com
}

\section{ABSTRACT}

This study objected to determine mechanical properties of sand moulding by conducting tensile test, compressive and shear test, and also permeability test. This study also had the other objective that was analyse clamshell (Placuna placenta) as mixture material for bentonite as binder in manufacturing sand moulding in order to reduce the usage of bentonite. The method that used in this study was pre-experimental method with One-Shot Case Study model. The best mechanical properties obtained on sample 3 clamshell $11 \%$, permeability results obtained was $190 \mathrm{ml} / \mathrm{min}$, tensile strength results obtained for the dry sand was $0.015 \mathrm{~kg} / \mathrm{cm}^{2}$, compressive strength obtained for the dry sand was $2.91 \mathrm{~kg} / \mathrm{cm}^{2}$, and the shear strength of sand moulding in dry condition was $0.92 \mathrm{~kg} / \mathrm{cm}^{2}$.

Copyright (C) 2018Journal of Mechanical Engineering Science and Technology

All rights reserved

Keywords: Mechanical properties, permeability, sand moulding, clamshell (Placuna placenta).

\section{Introduction}

Metal casting is process of processing material to produce various type of metal in various forms depending on the moulding. Metal casting is manufacture process by melting metal into liquid form then poured into moulding [1]. Thus, the system and casting process cannot be separated from moulding [2]. Casting is made of metal melted, poured into moulding then let the metal to be cool and freeze [3].

Commonly, the composition of sand moulding that used in casting consists of: silica sand, bentonite, water, carbon, and water-resistant powder [4]. Generally, binder which is used in sand moulding is bentonite. The use of bentonite as binder in sand moulding manufacture of sand due to its necessary properties that generate high binding capacity, being clay in wet condition and harden in dry condition, thus, manufacture of sand moulding is easy to be set up [5].

Manufacturing sand moulding is not only considering the binder, but also there are several things that need to be understand, that are the permeability and mechanical properties, permeability of sand moulding should be good, the poor permeability will cause defects on the results of the cast product, while permeability is influenced by the percentage of binder [6]. In addition, there are several mechanical properties that should include in standard value of sand moulding.

The binder that used in this study is bentonite, but the composition is reduced and added mixture material that is clamshell. Nowadays, utilization of clamshell is still to ornaments, cosmetics, mixed fodder. In previous study showed that clamshell can be used for mixture of paving blocks and concrete, so it is possible to be used for a mixture of sand moulding as binder mixture, the content of clamshell was dominated by calcium that up to $98.20 \%$ [7].

The use of clamshell as the mixture of paving blocks mentioned that composition of sand and clamshell with a ratio of 100\%:0\%, 90\%:10\%, 80\%:20\%, raw materials mixed with cement binder with a ratio of 1:4 [7]. According to this study showed that the best result of testing water absorption and compressive strength in paving block with composition of $80 \%$ sand and $20 \%$ clamshell, paving has moisture content of $2.94 \%$ and compressive strength of $46.79 \mathrm{MPa}$ that has met the standards. 
The previous study under the title "The Effect of Limestone and Quicklime Addition to K-300 Concrete Mixture" showed that this study using limestone as binder, the calcium content of the limestone has benefit as an adhesive, limestone is selected as binder due to its calcium content which its properties mixed with water can be hardened [8].

\section{Methodology}

The research design that used in this study was pre-experimental and used One-Shot Case Study model. The independent variable in this study using comparison of silica sand with clamshell as a binder of sand moulding. The percentage of silica sand were $88 \%, 85 \%$ and $82 \%$ and binder with percentage of $5 \%, 8 \%$ and $11 \%$. The dependent variables were permeability, tensile strength, compressive strength, shear strength. While the control variable of this study was water with the percentage of $5 \%$, clamshell that used had mesh size of 200 or fineness of $0.02 \mathrm{~mm}$, and silica sand with mesh size of 40 or fineness of $0.4 \mathrm{~mm}$.

The composition of the sand moulding that used in this study were:

1. $5 \%$ clamshell, $2 \%$ bentonite, $88 \%$ silica sand and $5 \%$ water,

2. $8 \%$ clamshell, $2 \%$ bentonite, $85 \%$ silica sand and $5 \%$ water,

3. $11 \%$ clamshell, $2 \%$ bentonite, $82 \%$ silica sand and $5 \%$ water.

\section{Results and discussion}

\section{A. X-Ray Diffraction Analysis}

The XRD characterization was conducted to clamshell to determine the grain size of clamshell before it used as binder in the metal casting. The XRD result could be seen in Table 1 and Figure 1.

The calculation result of clamshell crystal size obtained was $52.16 \mathrm{~nm}$. The crystal size of clamshell was different with the crystal size of eggshell. XRD result of sintered eggshell nanopowder at temperature of $1100^{\circ} \mathrm{C}$ was $59.7912 \mathrm{~nm}$. So the crystal size of clamshell was smaller than the eggshell [9].

Table 1. Phase Identification of Clamshell (Placuna placenta)

\begin{tabular}{cccccc}
\hline Material & \multicolumn{5}{c}{ X-Ray Diffraction (Correspond to peak) } \\
\hline Clamshell & Position (Pos) & $\begin{array}{c}\text { Intensity } \\
(\text { counts })\end{array}$ & $\begin{array}{c}\text { FWHM } \\
(\text { rad })\end{array}$ & $\boldsymbol{d}$-spacing $(\AA)$ & $\begin{array}{c}\text { Crystallite Size } \\
(\text { nm })\end{array}$ \\
\hline
\end{tabular}

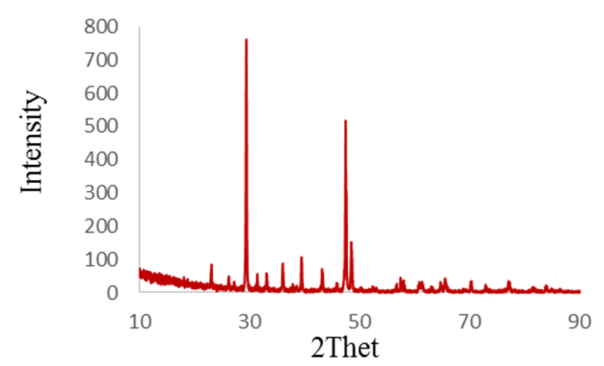

Fig. 1.Phase Identification of Clamshell (Placuna placenta) 


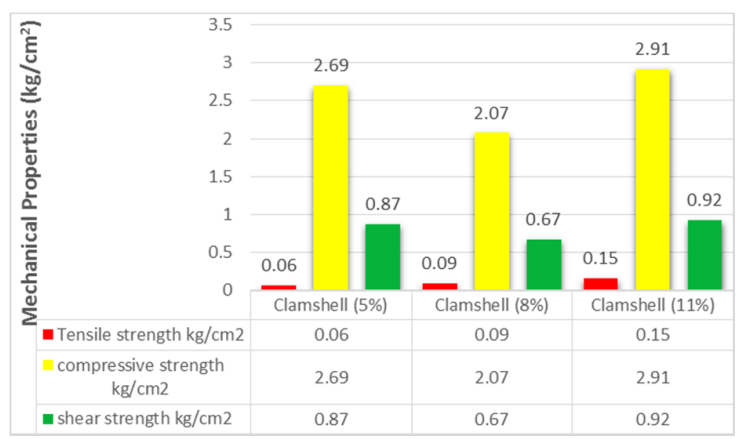

Fig. 2.Mechanical Properties Analysis Sand Moulding in Dry Conditions

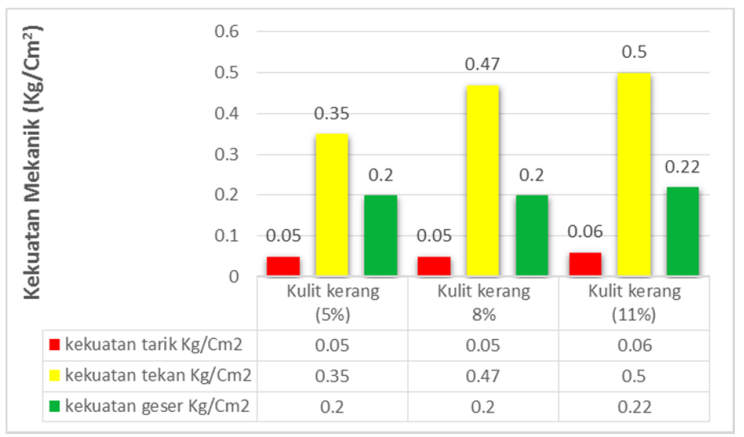

Fig. 3.Mechanical Properties Analysis of Sand Moulding in Wet Condition

\section{B. Mechanical Properties Analysis of Sand Moulding in Dry Condition}

According to the Figure 2, could be concluded that among samples which had the best mechanical properties such as tensile strength, compressive strength and shear strength was sample 3 with composition of $11 \%$ clamshell. In dry condition, the highest tensile strength of sand was 0.15 $\mathrm{kg} / \mathrm{cm}^{2}$, the strength was still within the limit that allowed for tensile strength, the standard value of tensile strength for sand moulding was 0.07 to $0.42 \mathrm{~kg} / \mathrm{cm}^{2}$. The highest compressive strength value was sample 3 with composition of $11 \%$ clamshell with the value of $2.91 \mathrm{~kg} / \mathrm{cm}^{2}$, this value included into standard value of compressive strength for sand moulding that was between 1.5 to $17.5 \mathrm{~kg} / \mathrm{cm}^{2}$. The highest shear strength also obtained at sample 3 with composition 11 clamshell, with shear strength $0.92 \mathrm{~kg} / \mathrm{cm}^{2}$, this value did not include in standard value of shear strength for sand moulding that was between 0.10 to $0.49 \mathrm{~kg} / \mathrm{cm}^{2}$. Previous study which conducted by Muzayyin (2017) who examined the sand moulding with composition of $10 \%$ bentonite, $85 \%$ silica sand and $5 \%$ water reached the tensile strength of $0.05 \mathrm{~kg} / \mathrm{cm}^{2}$, the compressive strength of $1.3 \mathrm{~kg} / \mathrm{cm}^{2}$, and the shear strength of $0.3 \mathrm{~kg} / \mathrm{cm}^{2}$. Compared with the result of clamshell, eggshell and pure bentonite, could be concluded that variation of $11 \%$ clasmshell and $2 \%$ bentonite had the lower mechanical properties compared with sand moulding which used eggshell as binder. But the value that reached by sample 3 with composition of $11 \%$ clamshell was closer to the standard shear testing results, so the results of $11 \%$ clamshell was able to be be used for sand moulding manufacture in order to reduce the usage of bentonite. The content of water and binder in dry condition, usually was lower than in wet condition, for the drying process [5], [10].

\section{Mechanical Properties Analysis of Sand Moulding in Wet Condition}

Figure 3 showed that sample which had the highest mechanical properties was sample 3 with composition of $11 \%$ clamshell. In wet condition, this sample had the highest tensile strength value that was $0.06 \mathrm{~kg} / \mathrm{cm}^{2}$, but the result was below the standard value of tensile strength, that was 0.07 to $0.42 \mathrm{~kg} / \mathrm{cm}^{2}$. The compressive strength value was $0.50 \mathrm{~kg} / \mathrm{cm}^{2}$, which included into standard value for compressive strength, which was between of 0.35 to $1.54 \mathrm{~kg} / \mathrm{cm} 2$, the more percentage of binder the higher compressive strength. This result consistent with the previous study which stated that increasing binder will increase the compressive strength [11], [12]. The highest shear strength value was $0.22 \mathrm{~kg} / \mathrm{cm}^{2}$ which included into standard value of shear strength, that was between 0.10 to 0.49 $\mathrm{kg} / \mathrm{cm}^{2}$. Previous study that examined sand moulding with composition of $10 \%$ bentonite, $85 \%$ silica sand and $5 \%$ water reached the tensile strength of $0.06 \mathrm{~kg} / \mathrm{cm}^{2}$, the compressive strength of 0.5 


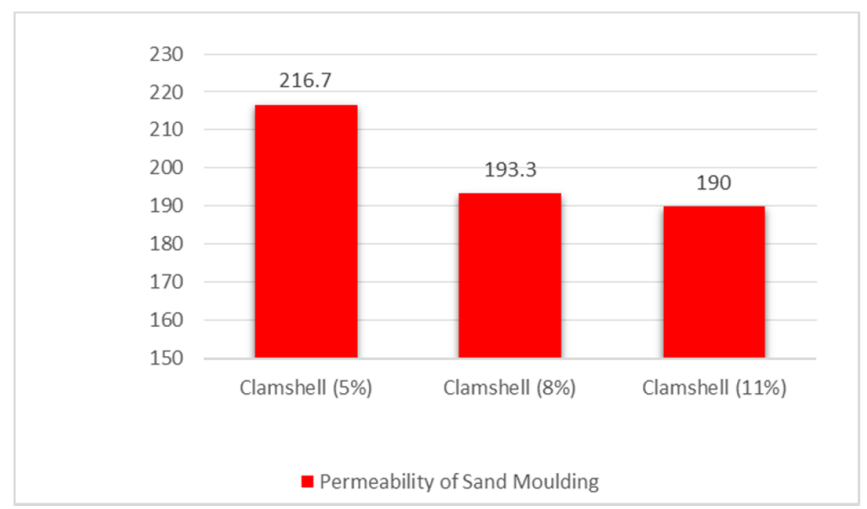

Fig. 4.Bar chart Sand Mould Permeability Testing Results of the variety of shells

$\mathrm{kg} / \mathrm{cm}^{2}$, and the shear strength of $0.22 \mathrm{~kg} / \mathrm{cm}^{2}$. After comparing the result of clamshell mixture and pure bentonite, could be concluded that in mechanical properties testing of sand moulding with $11 \%$ clamshell in wet condition was equal to the usage of $10 \%$ bentonite.

\section{Permeability Testing}

The permeability test result was showed at Figure 4, permeability was influenced by the grain size of sand and its percentage [6]. The characteristic of moulding was highly dependent on the grain size distribution of sand moulding, the percentage of binders and the percentage of water content.

Figure 4 showed permeability test results, the samples that had the highest permeability result was sample 1 with composition of 5\% clamshell with the value of $216 \mathrm{ml} / \mathrm{min}$, then in the second rank was sample 2 with the composition of $8 \%$ clamshell with the value of $193.3 \mathrm{ml} / \mathrm{min}$. The third rank was sample 3 with composition of $11 \%$ clamshell $11 \%$ with the valued of $190 \mathrm{ml} / \mathrm{min}$. The higher binder content in the composition of moulding would create a gap between the sand grains tightly, thus making the air got difficulty in flowing. If the sand mould had low permeability caused trouble in air flow through the sand grains. While the lower binder content in composition of moulding would create a gap between the sand grains loosely, thus air flowing easily. The level of permeability of the moulding was influenced by the binder [13]. According to this explanation, could be concluded about the permeability of dry sand that the sample which had low binder content would resulted high permeability because the binder did not fill the pores between the sand grains, thus the air flowed easily. This was proved in sample 1 with 5\% clamshell which had permeability of $216 \mathrm{ml} / \mathrm{min}$ while the sample 3 with $11 \%$ clamshell had the permeability of $190 \mathrm{ml} / \mathrm{min}$. The lower permeability result due to the high percentage composition of clamshell. The more the amount of binder which added to the sand would fill the pores between the sand grain and the permeability decreased. Inversely with mechanical properties result, the higher composition the higher mechanical properties of sand moulding [13].

\section{CONCLUSION}

Recommendation composition sand moulding was sample 3 with $11 \%$ clamshell with permeability result of $190 \mathrm{ml} / \mathrm{min}$, tensile strength result of $0.15 \mathrm{~kg} / \mathrm{cm}^{2}$, compressive strength result of $2.91 \mathrm{~kg} / \mathrm{cm}^{2}$ and shear strength result of $0.92 \mathrm{~kg} / \mathrm{cm}^{2}$.

\section{References}

[1] C. Saikaew dan S. Wiengwiset, "Applied Clay Science Optimization of molding sand composition for quality improvement of iron castings," Appl. Clay Sci., vol. 67-68, hal. 26-31, 2012.

[2] M. K. Joseph, F. Banganayi, dan D. Oyombo, "Moulding Sand Recycling and Reuse in Small Foundries," Procedia Manuf., vol. 7, hal. 86-91, 2017.

[3] T. Surdia dan S. Saito, "Pengetahuan Bahan Teknik," hal. 372, 1999.

[4] F. F. Bownes, "Sand Casting," in Castings, 1971, hal. 63-74. 
[5] Andoko, P. Puspitasari, A. A. Permanasari, dan D. Z. Lubis1, "Formula of Moulding Sand, Bentonite and Portland Cement toImprove The Quality of Al-Si Cast Alloy," J. Mech. Eng. Sci. Technol., vol. 1, no. 2, hal. 49-52, 2017.

[6] M. A. S. I Made Astika, DNK Putra Negara, "Pengaruh Jenis Pasir Cetak dengan Zat Pengikat Bentonit Terhadap Sifat Permeabilitas dan Kekuatan Tekan Basah Cetakan Pasir ( Sand Casting )," J. Ilm. Tek. Mesin Cakram, vol. 4, no. 2, hal. 132-138, 2010.

[7] E. W. Kusuma, "PAVING BLOCK O 1 e h : O 1 e h :," 2012.

[8] J. J. Darren, D. Gunaran, H. Hendy, dan E. K. Budirahardjo, "Pengaruh Penambahan Gabungan Batu Kapur the Effect dan Batu Kapur Padam pada Campuran Beton K-300," hal. 141-148.

[9] M. S. Jebeli dan W. Kurnianto, "Mechanical Properties and Permeability of Sand Casting Moulds with Eggshells Binder," vol. 2, no. 1, hal. 7-12, 2018.

[10] S. Priyadharsini dan P. Karunakaran, "Determination of the Physical Properties of Sand Moulding Bonded with Composite of Ipomoea Batatas and Bentonite with Casting Application," hal. 2913-2919, 2016.

[11]W. Yu, H. He, N. Cheng, B. Gan, dan X. Li, "Preparation and experiments for a novel kind of foundry core binder made from modified potato starch," Mater. Des., vol. 30, no. 1, hal. 210-213, 2009.

[12] Anon, "Sand/binders/sand preparation/mold \&amp; coremaking," Foundry Manag. Technol., vol. 124, no. $1,1996$.

[13] N. T. Herwido, P. Murdanto, dan P. Puspitasari, "Analisis Variasi Komposisi Fly Ash Dan Bentonit Pada," J. Mech. Eng. Sci. Technol., no. 1, hal. 1-11, 2016. 